* Mestre em Ciências Jurídicas (UFPB). Pós-graduado lato sensu em Direito Fundamentais e Democracia (Universidade Estadual de Paraíba). Bacharel em segurança pública (PMPB) e bacharel em direito (UEPB) e capacitado em análise criminal (SENASP). Ouvidor setorial e assessor da Corregedoria Setorial do $4^{\circ}$ Batalhão/PMPB e docente colaborador do Polo UNOPAR Guarabira. E-mail: allanjonesgba@hotmail.com

** Pós-Doutor em Sociologia e Teoria do Direito no Centro di Studi sul Rischio dalla Facoltà di Giurisprudenza dell Università del Salento. Doutor em Ciências Jurídico-Criminais pela Faculdade de Direito da Universidade de Coimbra. Mestre em Direito Penal pela faculdade de Direito do Largo São Francisco da Universidade de São Paulo. Professor da Universidade Estadual da Paraíba e docente colaborador no programa de pós-graduação em ciências jurídicas do centro de ciências jurídicas da Universidade Federal da Paraíba. E-mail: lucianonascimento@hotmail. com

*** Bacharel em Direito (UEPB). Bacharel em Segurança Públi-

\section{O INSTITUTO DA DELAÇÃo PREMIADA NO COMBATE AS ORGANIZAÇÕES CRIMINOSAS}

THE USE OF THE PLEA BARGAIN IN COMBATING CRIMINAL ORGANIZATIONS

\section{Allan Jones Andreza Silva* Luciano Nascimento Silva** Andrey Jonas Andreza Silva***}

Como citar: SILVA, Allan Jones Andreza; SILVA, Luciano Nascimento; SILVA, Andrey Jonas Andreza. O instituto da delação premiada no combate as organizações criminosas. Revista do Direito Público, Londrina, v. 13, n. 1, p. 110-149, abr. 2018. DOI: $\quad 10.5433 / 1980-511 X 2018 v 13 n 1 p 110$. ISSN: 1980-511X.

Resumo: Este artigo tem por escopo analisar o instituto da delação premiada a luz da Lei $\mathrm{n}^{\mathrm{o}} 12.850 / 13$, partindo-se de uma perspectiva metodológica dedutiva, utilizando-se de pesquisa bibliográfica para abordar o trato jurídico nacional. Para tanto, busca-se compreender sua pertinência para o combate às organizações criminosas, bem como verificar sua validade segundo ditames éticos e jurídicos. Inicia-se observando a influência destas organizações, sua engrenagem corporativa e a disponibilidade de meios mobilizados para auferir vantagens ilícitas, como também a dificuldade de enfrentamento pelo Estado, 
não apenas pela escassez ou precariedade de recursos, mas também pela burocracia processual que impossibilita efetivamente desmantelar tais organizações. Para superar esta problemática, a delação premiada demonstra ser um instrumento importante para a persecução penal, sobretudo quando balizada pelos procedimentos estatuídos pela lei $12.850 / 13$, corroborando para a concretização de uma política criminal comprometida com o bem-estar da população e a proteção do Estado Constitucional de Direito.

Palavras-chaves: Delação premiada.

Organização criminosa. Efetividade.

Combate.

Abstract: This study analyses the use of the plea bargain regulated in law $\mathrm{n}^{\mathrm{o}}$. 12.850/13. This paper employs a deductive methodological approach, using bibliographical research to address the tool's national legal tract. Thus, this research aims to understand the relevance of the plea bargain in combating criminal organizations, while verifying its validity according to ethical and legal standards. Therefore, this research commences observing the influence of these organizations, from their corporate gear to the broad availability of their resources used for illegal benefits. Moreover, this body of work explores the difficulties of the State in confronting criminal organizations, as they lack not only the resources, but also has procedural bureaucracy preventing an effective ca (PMPB), official da polícia military da Paraíba. E-mail: andrey_jonas@hotmail.com 
dismantling of these organizations. Aspiring to overcome this problem, plea bargaining proves to be an important tool for the prosecution, particularly when buoyed by the procedures laid down by law 12.850/13, corroborating the fulfillment of a criminal policy committed to the people's well-being and protection as guaranteed by the Constitutional Rule of Law. Keywords: Plea bargaining. Criminal organization. Effectiveness. Combat. 


\section{INTRODUÇÃO}

Vislumbra-se cotidianamente nos telejornais a incidência de violência. A criminalidade urbana parece bater à porta de todos. Além de escancarar uma realidade nacional de insegurança, estampa a deficiência estatal para conter este problema em dois âmbitos: primeiramente, no campo normativo, onde não é constatada a eficiência de mecanismos penalizantes para desestimular tais práticas, e, num segundo momento, observa-se a precariedade dos recursos mobilizados para a prevenção e enfrentamento qualificado desta circunstância.

Esta dificuldade se notabiliza principalmente quanto às medidas desenvolvidas para aplacar a criminalidade organizada, onde a sofisticação das estruturas, práticas e interligações praticamente neutralizam os efeitos das ações estatais dirigidas para investigá-las e combatê-las ${ }^{1}$. Notoriamente, a estrutura tradicional do sistema de justiça criminal, especificamente os recursos convencionais utilizados para a repressão à delitos mais comuns como furto, roubo etc., mostra-se inapropriada para aferir grandes resultados no combate à tais organizações e, quando muito, apenas possibilitam a prisão de uma pequena quantidade dos infratores, justamente os menos influentes ${ }^{2}$, retratando, desta maneira, uma pragmática impossibilidade de efetivo enfrentamento.

Diante desta deficiência/problema, o instituto da "delação

1 Segundo anota Lameirão (2014, p. 43), “[...] vale salientar que a dificuldade na prevenção e repressão qualificada das organizações criminosas se avoluma quando da análise do direito doméstico de cada país, pelo fato de nem todos possuírem sequer uma definição do que elas significam, leis específicas de combate ao crime organizado, sistema probatório vetusto, bem como despreparo e falta de infraestrutura mínima no tocante a atuação dos órgãos integrantes da persecução criminal, que permita, de forma eficaz, através da obtenção de provas consistentes, o seu desbaratamento".

2 Gonçalves e Baltazar Júnior (2016, p. 651) deixam claro a importância da delação premiada, sobretudo perante "[...] a dificuldade da Justiça Penal em recair sempre sobre os peixes pequenos ou soldados da organização, encarregados do serviço sujo, como os transportadores de droga, enquanto os mandantes restam protegidos pelo manto da organização lícita ou com aparência de lícita". 
premiada" emerge como alternativa para construção de soluções para questão. Muito embora esta detenha raízes históricas, apenas recentemente os operadores do direito tem atentado e dado notoriedade a este meio de obtenção de prova, sobretudo pelo uso constante no transcurso do processo investigatório da Operação Lava $\mathrm{Jato}^{3}$, sob formas de acordos que fizeram esta operação ganhar publicidade sem precedentes na história nacional.

Ciente destas condições, o presente artigo trata sobre o instituto da "delação premiada" atentando a sua instrumentalização como recurso apto ao combate das organizações criminosas, de maneira a buscar destacar seus aspectos controvertidos, sua importância e aplicação sob o plano jurídico nos dias atuais.

Metodologicamente, se utiliza de uma perspectiva dedutiva, recaindo sobre considerações quanto a sua construção teórica e técnica, para assentar o olhar sobre a realidade jurídica nacional e sua aplicabilidade atual. Deste modo, fora utilizado como recurso a pesquisa bibliográfica, iniciando pela compreensão do que é organização criminosa, segundo o ordenamento pátrio vigente, para, por conseguinte, entender a relevância e aplicabilidade da deleção premiada para o combate a tal problemática, partindo-se de sua análise conceitual, histórica e quanto a sua execução no âmbito judicial.

\section{AS ORGANIZAÇÕES CRIMINOSAS}

3 Até 23/10/2017, a Operação Lava Jato, que visa apurar denúncias de corrupção envolvendo a Petrobrás, se destaca por utilizar o instituto da colaboração premiada como carro chefe para desbaratar o esquema de corrupção que envolve a estatal. Até o momento, 158 acordos de colaboração foram homologados pela Justiça Federal do Paraná, local onde se concentram as investigações. Após os acordos de colaboração, foram descobertas evidências de crimes de corrupção que envolve quantias superiores a R\$ 6 bilhões de reais. Em decorrência dos acordos de colaboração, cerca de R $\$ 10$ bilhões de reais estão em processo de recuperação, sendo $\mathrm{R} \$ 756,9$ milhões objeto de repatriação e $\mathrm{R} \$ 3,2$ bilhões em bens de réus já bloqueados. (MPF, 2017) 
Ao adentrar no estudo sobre a delação premiada é necessário inicialmente tecer alguns comentários sobre para qual fim ela tem sido fundamentalmente aplicada, ou seja, a principal problemática para qual ela tem sido instrumentalmente empregada como forma de enfrentamento, logo inicialmente tratar-se-á de analisar o que seriam as organizações criminosas.

Elas se popularizaram recentemente em razão dos noticiários televisivos e até filmes que retratam, seja sob a forma de documentários ou ficção, as ações criminosas ou investidas policiais para desbaratamento destas organizações pelo mundo. Ao mesmo tempo, em face da constância da ocorrência dos delitos cometidos em concurso de agentes e de modo organizado e bem planejado, pode-se deduzir que aparentemente os infratores da lei tem percebido que ações isoladas e descoordenadas, quando não são prontamente rechaçadas pelos órgãos policiais, não têm possibilitado a percepção dos resultados almejados, o que pode ter possibilitado insurgir um crescente interesse na filiação às empresas do crime.

Acrescente-se ainda que as organizações criminosas, quando alicerçadas por padrões de gestão fundados numa meticulosa estratificação funcional e no uso avançado da tecnologia, alcançam incríveis patamares de coordenação, aparelhamento e poder econômico, social e, muitas vezes, até político, tornando o enfrentamento estatal destes grupos muitas vezes inócuo. Como exemplo, acredita-se que a organização japonesa Yakusa possua uma receita estimada em 80 bilhões de dólares advindos do comércio de entorpecentes, jogos de azar a extorsão (ÉPOCA NEGÓCIOS, 2014).

Não obstante, de início é necessário atentar às considerações 
de Lameirão (2015, p. 09), quando este informa que a criminalidade organizada é uma fenomenologia muita antiga, citando, por exemplo, as associações italianas, as tríades chinesas e a Yakusa japonesa, onde teriam origem nos séculos XVI e XVII, como movimento camponês contrahegemônico ${ }^{4}$. Por conseguinte, é importante destacar que suas atuais configurações são resultantes de um processo histórico permeado por uma permanente atuação às margens das legislações vigentes, fazendo-a caracterizar-se como influxo de uma ordem jurídica instituída, mas eticamente consolidada pelo fortalecimento dos laços entre seus membros (inclusive através de juramentos) e por uma postura social e econômica dissimulada, de modo que a ocultação das atividades delituosas e a própria estrutura da organização era garantida pelo sigilo dos membros, lavagem de dinheiro, dentre outros, medidas estas que possibilitavam uma aparente adequação legal.

Desta maneira, destaca-se que seu real empoderamento ocorreu quando passaram a integralizar-se com o mercado financeiro e aos avanços tecnológicos, que permitiram a realização de práticas como a lavagem de dinheiro bem como facilitaram a aquisição de aviltante material bélico e até mesmo sua inserção no campo político.

Tratando-se especificamente da realidade brasileira, Lameirão (2015, p. 12) destaca o "cangaço", uma forma de organização criminosa existente no sertão nordestino entre os séculos XIX e XX, voltada para a prática de extorsões, sequestros e saques, tendo como representante mais conhecido Virgulino Ferreira da Silva, vulgo "Lampião". Mais recentemente, constata-se a estruturação de organizações que surgiram

4 "A mais famosa das organizações criminosas do ocidente é a Máfia Italiana. Durante a Idade Média, mais precisamente, na época feudal, momento histórico de exploração dos camponeses, exsurge, no sul da Itália, um grupo de trabalhadores, visando implementar uma política fundiária, que se rebela para eliminar barreiras que impossibilitam a ascensão social da classe" (LAMEIRÃO, 2015, p. 9). 
das penitenciárias a partir do final do período ditatorial, a exemplo do "Terceiro Comando", "Falange Vermelha", "Primeiro Comando da Capital - PCC", instituídas para garantir condições materiais e de sobrevivência para detentos, em troca de fidelidade dentro ou fora das penitenciárias.

Notadamente, as motivações que originaram suas criações foram ampliadas e hoje constituem simbolicamente um "partido" que serve de referência "político-criminal" para delinquentes. Entenda-se tal questão como uma forma de aproximação para construção de grupos criminosos dirigidos para garantir benefícios próprios, como melhores armas, maior influência em pontos de tráfico de drogas e proteção interna entre seus membros. Atualmente, para muitos jovens delinquentes a participação em grupos como estes detém uma característica simbólica semelhante a torcer por um time de futebol, participar de um clube, etc.

Por muitos anos, a definição de organização criminosa ficou a cargo da doutrina e da jurisprudência, uma vez que não existia conceituação legal para o termo na Lei 9.034, de 03 de maio de 1995, que tratava sobre os meios operacionais para prevenção e repressão à tais grupos, mas não identificava claramente sua extensão. Em 2000, o Brasil assinou a Convenção das Nações Unidas Contra o Crime Organizado Transnacional, conhecida também como a Convenção de Palermo ${ }^{5}$, se comprometendo em colaborar com outros países para o trato do problema. A partir da edição da lei 12.850/13, especificamente através do art. $1^{\circ}$, $\S 1^{\circ}$, passou-se a compreendê-las segundo uma conceituação legal clara. Muito embora alguns ainda possam confundi-la com o delito

5 Segundo Correia e Oliveira (2016, p. 148), “[...] este é, atualmente, o principal instrumento global de combate ao crime organizado transnacional, pois seu objeto consiste em promover a cooperação entre os Estados participantes e visa coibir o crime organizado transnacional. Orientada pelas diretrizes da Convenção de Palermo, surge a necessidade da adequação, inclusive com adoção de novas medidas, assim, novas leis diferenciadas se fazem necessárias para tanto". 
de associação criminosa (art. 288 do Código Penal), a organização criminosa tem caracterização peculiar, de tal maneira que Nucci (2015, p.13) a descreve como:

[...] associação de agentes, com caráter estável e duradouro, para o fim de praticar infrações penais, devidamente estruturada em organismo preestabelecido, com divisão de tarefas, embora visando ao objetivo comum de alcançar qualquer vantagem ilícita, a ser partilhada entre os seus integrantes.

Nota-se que para ser tratada como organização, além da composição mínima de 04 pessoas (critério objetivo de política criminal adotado pelo legislador pátrio), é necessário o arranjo funcional e hierárquico ${ }^{6}$ estruturalmente estabelecido por liame intersubjetivo com animus estável ou por lapso temporal duradouro. Assim, acaba adotando um modelo de gestão estratificado e estável similar às grandes empresas, o que as tornas peculiares às demais formas de criminalidade.

Assim, para ser tratada como organização criminosa é necessário a existência de diferentes níveis de poder hierárquico e funcional entre seus membros. Assim, deve existir a função de chefia, relacionada com o dever de gerir o patrimônio, fiscalizar os subordinados etc., bem como são necessárias funções subordinadas, relacionadas a execução de ordens, segurança dos membros do alto escalão, arrecadação de valores obtidos por meios ilícitos, execução de sanções aos inadimplentes e demais componentes que feriram alguma das regras da organização, além de

6 Segundo Correia e Oliveira (2016, p. 147), “[...] a estrutura hierárquico-piramidal é uma das maiores características das organizações criminosas. Estruturam-se como se fossem verdadeiras empresas acompanhando o mercado, demandando o que é ilícito para promoverem suas práticas proibidas e tendo, com isso, lucros faraônicos". 
outros afazeres operativos, necessários a perpetuação do grupo e garantia do proveito do dinheiro aferido pela ação ilícita.

A obtenção de vantagem, direta ou indireta, de qualquer natureza constitui a meta principal de qualquer organização criminosa. Neste norte, o legislador não impôs limitações claras sob quais seriam estas vantagens, tratando apenas de inserir o termo "qualquer natureza", no entanto, sabe-se que o interesse econômico é o principal, mesmo em concomitância com outros.

Em face da definição legal, instituída no $\S 1^{\circ}$ do $\operatorname{art.1^{\circ }}$ da Lei 12.850/2013, o legislador ao impor que esta vantagem ilícita seja percebida pela prática de delitos com pena máxima superior a quatro anos ou transnacionais, limitou o alcance lógico-criminal, o que não deve ser visto com bom alvitre.

Corroborando desse entendimento, Nucci (2015, p. 14) relata que “[...] não há sentido em se limitar a configuração de uma organização criminosa, cuja atuação pode ser extremamente danosa à sociedade, à gravidade abstrata de infrações penais [...]", observa-se a possibilidade de realização reiterada de contravenções penais ou delitos com pena abstrata inferiores e que, nem por isso, deixam de ser práticas maléficas a sociedade, mas sem legalmente ser considerada como organização criminosa.

Ultrapassadas as considerações iniciais, apontar-se-ão algumas das características marcantes dessas "empresas do crime". A primeira e mais peculiar, é a organização estrutural e funcional, como já mencionado, o que lhes dão uma falsa aparência empresarial em face da existência de uma complexa rede de cargos e funções com atividades especificamente delimitadas de cada integrante. Nessas organizações, os cargos de chefia, coordenação direta e execução são bem definidos, tendo cada 
elemento uma atribuição que qualifica o trabalho e expande a atuação da organização.

Em consequência das especificações de cada função, surge outra característica que é a seletividade no ingresso. De modo semelhante a uma empresa privada, os chefes das organizações selecionam os membros pelo mérito, fidelidade ou capacidade colaborativa, até mesmo como forma de proteção para os negócios tendo em vista a possiblidade de ingresso de agente estatal infiltrado.

Para possibilitar a movimentação sigilosa de recursos financeiros, as organizações também utilizam a sofisticação e emprego de avançado aparelhamento nas suas ações, retratando que adota como uma de suas técnicas de gestão a busca pelo aperfeiçoamento dos seus métodos como, por exemplo, o uso de recursos tecnológicos avançados, segurança da informação, etc.

Em muitos casos, a atividade criminosa é exercida com aquiescência do poder público, em face da influência exercida por alguns de seus membros perante os representantes das instituições estatais que, em tese, seriam responsáveis pela repressão ao grupo delinquente.

Isso ocorre porque as organizações possuem elevado poder financeiro e se valem da corrupção de agentes públicos para garantir o sigilo e perpetuação de suas ações, não obstante também poderem utilizar-se do seu poder beligerante para também exercer influência perante os servidores estatais. Essa circunstância arrefece a execução das ações de investigação e persecução penal, pois quem deveria coibir tais práticas fatalmente usará diferentes formas para ocultar a existência da criminalidade organizada ou dissimulará medidas de enfretamento, cujos resultados práticos são inócuos.

Além do mais, o silêncio protagonizado por funcionários 
públicos constitui um fator assecuratório da obscuridade das ações delituosas da organização que pode funcionar até mesmo como medida incentivadora a execução de outras práticas criminosas. Ainda assim, essa postura dos representantes estatais faz com que os elementos do alto escalão da organização permaneçam sistematicamente anônimos e, muito embora, algum dos integrantes da base organizacional seja preso, isso não possibilitará que os demais envolvidos possam ser definitivamente responsabilizados, garantindo a perpetuação de toda rede criminosa.

Possivelmente, advém deste contexto a maior barreira encontrada pelas forças de enfrentamento estatais para o combate as organizações criminosas, uma vez que a coleta probatória fica comprometida devido ao imperioso silêncio que barra os avanços das investigações policiais.

Neste viés, a atuação da delação premiada constitui a medida com maior possibilidade de sucesso, pois ao utilizar-se de um processo de barganha com o criminoso ${ }^{7}$, este tende a romper o silêncio e expor toda a estrutura organizacional, circunstância propícia a execução de ações capazes de sobrepujar as artimanhas montadas pelo sistema criminoso e angariar resultados bem mais importantes que apenas a prisão do delator.

\section{CONCEITO E EVOLUÇAO HISTÓRICA DA DELAÇÃO}

Precipuamente, deve-se conceituar o que seria o instituto conhecido como delação premiada. O termo delação, que deriva do latim delatione, significa denunciar, revelar. Por sua vez, premiada significa recompensar ou pagar a alguém um prêmio por algo feito que

7 Em decorrência desta circunstância, alguns autores chegam a tratar a resultante deste processo de delação como Justiça Penal Negociada (SILVA, 2017; WAGNER, ZART, 2016; GOMES; SILVA, 2015), Justiça Criminal Negocial (VASCONCELLOS, 2015; MENDES, 2017) ou, por vezes, ainda tratada por esses autores como Justiça Consensuada. 
o faça merecer. Em apertada síntese, delação premiada significa prestar informações com o fim de obter alguma forma de benefício individual. Ao tratar da questão em pauta pode-se dizer que consiste em denunciar outros participantes de uma organização ou seu modus operandi em troca de uma apreciação mais benéfica de sua conduta. Conforme definição feita por Cibele Benevides Guedes da Fonseca (2015, p. 05):

Colaboração premiada é uma técnica especial de investigação que estimula a contribuição feita por um coautor ou partícipe de crime em relação aos demais, mediante o benefício, em regra, de imunidade ou garantia de redução da pena ou de concessão de liberdade.

Pode-se encontrar relatos da aplicação da delação premiada até mesmo na Bíblia, na oportunidade em que Judas Iscariotes delatou Jesus de Nazaré em troca de moedas. Mais à frente, durante o período da Inquisição na Idade Média, ponderava-se o valor da delação, feita em momento de confissão sob tortura, de acordo com a intensidade do sofrimento enfrentado como maneira de assegurar a verossimilhança das informações, de tal sorte que " [...] se o co-réu confessava de forma espontânea, o entendimento era que ele estava inclinado a mentir em prejuízo de outra pessoa, diferentemente daquele que era torturado [...]" (DIAS, 2014). Desta forma, acreditava-se que as declarações feitas sob extrema dor eram verdadeiras tendo em vista as circunstâncias limites em que se encontrava o indivíduo.

No Brasil, a primeira previsão normativa sobre delação premiada foi apontada nas Ordenações Filipinas (1603-1867), que descrevia a necessidade de um livro específico para anotações das delações relacionadas aos crimes de falsificação de moeda. Ainda neste 
período, pode-se destacar a delação premiada realizada pelo Coronel Joaquim Silvério dos Reis, durante o período da Inconfidência Mineira, que, em troca de benefícios particulares, tais como o perdão de suas dívidas com a Coroa Portuguesa, delatou o movimento e os colegas participantes, dentre os quais Joaquim José da Silva Xavier (Tiradentes) que foi apontado como chefe do movimento e condenado à morte por enforcamento pelo crime de lesa-majestade (traição cometida contra a pessoa do Rei).

Durante o Regime Militar também foi estimulado o uso da delação para identificar e investigar aqueles que não concordavam com as ações governamentais, tratando-se tais medidas como ações de inteligência contra investidas terroristas, milícias e grupos ou organizações paraestatais que atuavam em desacordo com a política de segurança nacional.

Também é importante destacar que a delação premiada é um meio de obtenção de prova que se espalhou pelo mundo, encontrando exemplos de sua aplicação em vários países, a exemplo da Itália, que a utilizou como um dos principais instrumentos para o combate a organização criminosa "Cosa Nostra".

Neste ínterim, conforme destacam Quezado e Vierginio (2009), os acordos de colaboração processual se espalharam pela legislação de diversificados países, inclusive instituindo diferentes denominações aos delatores como: "collaboratori della giustizia” no direito italiano, "crown witness " entre as nações anglo-saxãs, “kronzeugen” nos países de língua alemã, “arrepentidos” pelos espanhóis, dentre outros.

Estes autores ainda reconhecem que, mesmo constituindo uma prática antiga e, portanto, presente em diferentes momentos históricos, em alguns países como Japão instituíram verdadeiras proibições legais 
a delação premiada por considerá-la uma prática odiosa (QUEZADO; VERGINIO, 2009).

A atual ordem jurídica brasileira não só tem acatado a possibilidade de sua aplicação, como tem sido um instrumento reproduzido em diversificadas legislações específicas. Assim, muito embora possa gerar críticas em face dos aparentes conflitos gerados com a base principiológica da Constituição Federal de 1988, dentre os quais o "nemo tenetur se detegere", "in dubio pro reo", ampla defesa e o contraditório, de outros, ainda assim a delação premiada tem encontrado amparo na supremacia do interesse público, na tutela da ordem e segurança pública, na proteção dos bens jurídicos tutelados e a sustentação de que esta não constitui uma prova absoluta, ou seja, que ela figura apenas como elemento norteador das investigações criminais e que precisa ser analisada sua verossimilhança em conjunto com as provas produzidas a partir dela.

Por conseguinte, é importante verificar que sob a égide da atual constitucional foi promulgada a Lei ${ }^{\circ} 8.072$, de 25 de julho de 1990 (Lei dos Crimes Hediondos), que em seu art. $8^{\circ}$, parágrafo único, deu um importante passo no trato do instituto da delação premiada ao disciplinar que o participante da quadrilha que apontasse os demais componentes levando o seu desmantelamento teria a pena reduzida de um a dois terços.

A partir de então vê-se diversos dispositivos semelhantes sendo adotados pelo legislador nacional, como na Lei $\mathrm{n}^{\circ} 9.080$, de 19 de julho de 1995 que inseriu o $\S 2^{\circ}$ do art. 25 na Lei n ${ }^{\circ} 7.492$, de 16 de junho de 1986 (Lei do Colarinho Branco ou dos crimes contra o Sistema Financeiro), possibilitando uma redução de um a dois terços da pena para aqueles que em confissão espontânea revelar à autoridade policial ou judicial toda a trama delituosa. 
Ainda assim, pode-se verificar que atualmente o instituto está presente em diversificadas previsões normativas como: o art. 16 da Lei $\mathrm{n}^{\text {o }}$ 8.137, de 27 de dezembro de 1990 (Lei dos Crimes contra a Ordem Tributária); o art. 159, $\S 4^{\circ}$, do Código Penal, com redação dada pela Lei $\mathrm{n}^{\circ}$ 9.269, de 02 de abril de 1996; o art. $1^{\circ}, \S 5^{\circ}$, da Lei ${ }^{\circ} 9.613$, de 03 de março de 1998 (Lei dos crimes de Lavagem de dinheiro); os arts. 13 a 15 da Lei no 9.807, de 13 de julho de 1999 (Lei de Proteção a Vítimas e Testemunhas); o art. 41 da Lei ${ }^{\circ}$ 11.343, de 23 de agosto de 2006 (Lei de Tóxicos); o art. 86 da Lei no 12.529, de 30 de novembro de 2011 (Lei Antitruste), além dos arts. 16 e 17 da Lei $n^{\circ} 12.846$, de $1^{\circ}$ de agosto de 2013 (Lei Anticorrupção).

Mesmo desta forma, a delação premiada tem sua mais recente presença registrada nos arts. $4^{\circ}$ a $7^{\circ}$ da Lei $n^{\circ} 12.850$, de 2 de agosto de 2013 (Lei de Combate ao Crime Organizado), onde fora adotada nova nomenclatura, substituindo-se o termo "delação premiada" por “colaboração premiada". Esta alteração se deve ao fato de que parte da doutrina critica a denominação do instituto por, em tese, estampar a infringência de preceitos éticos, sendo o termo "delação" associada de forma preconceituosa à deslealdade e a traição.

A partir deste contexto, destaca-se que através da delação premiada operacionalmente intenciona-se alcançar o chamado "dedurismo", muito criticado por parte da doutrina por ferir "preceitos éticos", a fim de que se possa obter a maior quantidade de informações que levem aos demais componentes ou meios que possam ajudar no desmantelamento da organização, mediante promessa de benefício, seja ele redução de pena ou até mesmo o perdão judicial. Porém, existe uma série de regras que balizam o instituto, de maneira que, ao revés do que se pensa, não constitui tão somente em delatar o coautor de crime para 
assim usufruir dos benefícios concedidos pela Justiça.

\section{DELAÇÃO PREMIADA À LUZ DA LEI 12.850/13}

A Lei 12.850/13, também chamada de Lei de combate às organizações criminosas, em seu art. $3^{\circ}$, traz todo um rol de mecanismos a serem aplicados na investigação de fatos relacionados a este tipo de empreendimento criminoso, quais sejam: (a) a colaboração premiada; (b) a captação de sinais eletromagnéticos, ópticos ou acústicos; (c) a ação controlada; (d) o acesso a registros de ligações telefônicas e telemáticas, dados cadastrais de bancos de dados públicos ou privados e a informações eleitorais ou comerciais; (d) a própria interceptação de comunicações telefônicas e telemáticas; (e) o afastamento do sigilo financeiro, bancário e fiscal; (f) a infiltração de policiais na atividade investigada; (g) a cooperação entre instituições e órgãos federais, distritais, estaduais, e municipais na busca de provas e informações de interesse da investigação, ou da instrução criminal.

Os termos em que essa colaboração premiada pode ser legitimamente realizada estão previstos nos arts. $4^{\circ}$ e seguintes, oportunidade na qual são abordados os requisitos, os procedimentos de celebração do acordo, as condições para homologação judicial e os possíveis benefícios ao delator.

Ainda que não expresso, o requisito basilar para admissibilidade da cooperação é a existência de um concurso de pessoas, de tal maneira que não importa se o delator esteja na condição de autor, coautor, participe dos delitos operativos da organização criminosa, ou ainda seja um integrante de menor importância desta.

Por conseguinte, é importante destacar que a celebração do 
acordo de colaboração pode-se dar em dois momentos: a) durante o período investigatório, oportunidade na qual poderá ser concedido o perdão judicial ou até a substituição da aplicação da pena convencionada para a conduta do delator, por prisão domiciliar; b) posteriormente à sentença, quando importará em redução de até metade da pena ou progressão de regime. Anote-se que o critério decisivo para concessão de qualquer benefício, em quaisquer das fases tratadas será a eficácia da colaboração, que, diga-se de passagem, constituirá uma medida pessoal, incomunicável aos demais investigados, pois o acordo vincula apenas as partes envolvidas (delator, acompanhado de seu defensor, e o Delegado ou representante do Ministério Público).

Emerge deste contexto, um dos primeiros pontos controvertidos do processo de colaboração, qual seja: o evidente comprometimento da isonomia material dos investigados, pois muito embora vigore o Princípio da Individualidade da Pena, uma das consequências práticas da aplicação deste instituto poderá ser uma discrepância do trato penal, pois "réus em idêntica situação jurídico-penal receberiam tratamento [bem] diferenciado" (SANTOS, 2016, p. 68).

Neste sentido, pode-se observar a previsão contida no caput do art. $4^{\mathrm{o}}$ :

Art. $4^{\circ} \mathrm{O}$ juiz poderá, a requerimento das partes, conceder o perdão judicial, reduzir em até $2 / 3$ (dois terços) a pena privativa de liberdade ou substituí-la por restritiva de direitos daquele que tenha colaborado efetiva e voluntariamente com a investigação e com o processo criminal $[\ldots]$

Nota-se que o legislador impõe alguns requisitos para obtenção dos benefícios, como a voluntariedade do agente, do contrário tratar-se-ia 
de uma medida coercitiva ilegal passível de nulidade (GOMES; SILVA, 2015 , p. 170), tanto é que a qualquer momento o colaborador pode se retratar, ainda que isso prejudique a garantia de verossimilhança das informações prestadas. Outro requisito é a efetividade da colaboração, que tem como requisitos os itens citados no próprio artigo $4^{\circ}$ :

I - a identificação dos demais coautores e partícipes da organização criminosa e das infrações penais por eles praticadas;

II - a revelação da estrutura hierárquica e da divisão de tarefas da organização criminosa;

III - a prevenção de infrações penais decorrentes das atividades da organização criminosa;

IV - a recuperação total ou parcial do produto ou do proveito das infrações penais praticadas pela organização criminosa;

V - a localização de eventual vítima com a sua integridade física preservada.

Segundo leitura do parágrafo $1^{\circ}$ do art. $4^{\circ}$, mesmo após a satisfação de um ou mais dos requisitos anteriores, ainda será necessário a avaliação da personalidade do colaborador, a natureza, as circunstâncias, a gravidade e a repercussão social do fato criminoso e a eficácia ${ }^{8}$ da colaboração para a concessão do benefício. Satisfeitos todos os requisitos, o juiz poderá homologar os termos do acordo e conceder a título de recompensa os benefícios ajustados.

Também é importante destacar que, mesmo a legislação definindo a concessão da redução da pena em até dois terços, não necessariamente o acordo tratará do quantum máximo e, mesmo que assim

8 Segundo ensinamento de Renato Brasileiro (2015, p. 536-537) “ [...] não basta a mera confissão acerca da prática delituosa. Em um crime de associação criminosa, por exemplo, a confissão do acusado deve vir acompanhada do fornecimento de informações que sejam objetivamente eficazes, capazes de contribuir para a identificação dos comparsas ou da trama delituosa". 
o trate, também dependerá da efetividade das informações prestadas,

o que constitui uma medida apta a garantir a proporcionalidade dos benefícios cedidos, além de transparecer segurança jurídica ao acordo.

Assim, na hipótese do perdão judicial ${ }^{9}$, deve a colaboração ser de grande relevância para as investigações ou processo penal, podendo o delegado de polícia, nos autos do inquérito policial, com a manifestação do Ministério Público, ou este a todo tempo, representar ao juiz pela sua concessão. "O juiz, também, na sentença de mérito poderá adequar a proposta ao que melhor indicar o caso concreto, inclusive tendo em vista o grau de efetividade da colaboração e as circunstâncias pessoais do agente" (GRECO FILHO, 2014, p.27)

Além das hipóteses previstas no caput do artigo no que tange aos benefícios concedidos ao delator, o $\S 4^{\circ}$. traz a possibilidade de $o$ Ministério Público deixar de oferecer denúncia se o colaborador, além de satisfazer os requisitos já esmiuçados, não for o líder da organização criminosa e for o primeiro a prestar colaboração, o que deve constar no bojo do acordo a ser homologado pelo juiz.

Em sendo a colaboração feita após a sentença, a legislação em comento ainda traz a previsão de benefício ao delator, que terá a pena reduzida até a metade ou será admitida a progressão de regime a depender dos já relatados requisitos expostos acima.

Segundo visão de Vicente Greco Filho (2014, p. 26), a figura ora estudada possui três fases: negociação/acordo, homologação

9 Para o STF: “O acórdão embargado não deixou qualquer margem para dúvida quanto ao fato de que o embargante merecia a redução da pena pela colaboração para a descoberta de outros corréus, mas não fazia jus ao perdão ou a uma diminuição de pena em maior amplitude, porque a sua colaboração não teve continuidade durante o andamento da ação penal. Pelo mesmo motivo, não faz jus à substituição da pena prevista no art. $4 .^{\circ}$ da Lei 12.850/2013. Embargos de declaração não conhecidos. Reconheceu-se o caráter meramente protelatório dos embargos e decretou-se, por consequência, o trânsito em julgado da condenação, com determinação de início imediato da execução da pena, independentemente de publicação do acórdão" (AP 470 MG, Tribunal Pleno, Rel. Joaquim Barbosa, DJ 13.11.2013). 
e sentença.

A negociação sempre será procedida entre delegado de polícia e o delator acompanhado de seu advogado com a supervisão do Ministério Público, nos casos de sua ocorrência durante o Inquérito Policial, ou deste com o delator acompanhado de seu advogado, nos casos da ocorrência durante o processo penal. No acordo constará apenas a celebração dos termos ajustados entre a partes para se iniciar a colaboração, podendo ou não constar o possível benefício a ser percebido pelo delator, o que também não vincula o juiz a concedê-lo quando da prolação da sentença, uma vez que, como já fora dito, no transcurso da fase processual ainda serão analisadas a verossimilhança das informações prestadas e a eficácia da colaboração para a persecução penal.

Desta maneira, concorda-se com o posicionamento de Greco Filho (2014, p 26) quando este conclui que “[...] o acordo é, portanto, apenas uma proposta, de que poderá constar o possível benefício a ser aplicado, mas que não vincula o juiz da sentença, nem mesmo se ele próprio tenha homologado o acordo". Também é importante frisar que nesse momento o juiz não participa das negociações ${ }^{10}$.

$\mathrm{O}$ art. $6^{\mathrm{o}}$ estipula a forma de como deve ser o acordo de colaboração, devendo ser escrito e conter os seguintes elementos:

I - o relato da colaboração e seus possíveis resultados; II - as condições da proposta do Ministério Público ou do delegado de polícia;

III - a declaração de aceitação do colaborador e de seu defensor;

IV - as assinaturas do representante do Ministério

10 "Desvirtuando a operacionalidade do referido instituto, observa-se uma participação do juiz Sergio Moro no transcorrer das investigações da Operação Lava-Jato conforme matéria exibida no site do Jornal Correio Brasiliense, onde Davi Teixeira de Azevedo, professor de Direito Penal da USP, afirma que ocorre a prática de 'prender para delatar'. Nesse norte, o magistrado estaria se valendo arbitrariamente de prisões preventivas para forçar os acordos de delação". (VALADARES, 2015) 
Público ou do delegado de polícia, do colaborador e de seu defensor;

V - a especificação das medidas de proteção ao colaborador e à sua família, quando necessário.

A fase subsequente trata-se da homologação do acordo. Nesta, o juiz irá verificar sua regularidade, legalidade e voluntariedade, podendo para este fim, sigilosamente, ouvir novamente o colaborador na presença de seu defensor. Neste interim, ressalta-se que a homologação do acordo não vincula a decisão/sentença do magistrado, sobretudo porque este pode até recusar a homologação da proposta se esta não atender aos requisitos supracitados, ou ainda adequá-la ao caso concreto.

Por fim, a última fase para a efetivação da deleção premiada é a sentença, onde o juiz analisará pormenorizadamente os efeitos da colaboração, concedendo ou não o benefício, fazendo a sua dosimetria frente aos resultados alcançados, ou seja, uma análise no campo formal e material dos requisitos tratados na legislação para fins de aplicabilidade dos benefícios.

Caso uma das partes (delator/Ministério Público) rescinda o acordo, as provas que por ventura incriminem o colaborador não poderão ser aplicadas exclusivamente em seu desfavor conforme prescreve o $\S 16$ do art. $6^{\circ}$. Deste modo, entende-se que este seja um mecanismo de defesa criado pelo legislador contra eventuais acordos falaciosos, o que ocasionariam sentenças equivocadas, colocando em xeque a eficiência do dispositivo.

Não obstante, mesmo sendo beneficiado com o perdão judicial ou não sendo denunciado pela autoridade ministerial, pode o colaborador ser inquirido por iniciativa das partes ou da autoridade judicial sempre que suas declarações forem pertinentes, sobretudo para fins de garantia 
da ampla defesa e contraditório.

Para se chegar a maior fidelidade nas informações prestadas pelo delator, o registro dos atos de colaboração será feito sempre que houver possiblidade por recursos tecnológicos de gravação digital ou técnica similar, inclusive audiovisual, a fim de que a análise de mérito seja a mais fiel possível.

De acordo com a explicação de Bittar e Pereira (2011), a colaboração não é equivalente à prova testemunhal, pois neste caso a pessoa presta esclarecimentos adotando uma posição passiva, enquanto que o delator possui uma condição ativa (além de ser autor ou coautor de algum delito, também assume uma postura de acusador dos demais infratores com os quais interagia). Não obstante, é sempre importante destacar que a delação premiada é um meio de obtenção de prova e não uma prova propriamente dita, ela irá possibilitar ações investigativas que poderão ratificar as informações prestadas ou contestá-las, de acordo com sua verossimilhança.

Ao final, percebe-se a exigência contínua da presença do defensor a fim de assegurar o pleno exercício do direito de defesa, da mesma forma que nenhuma garantia seja ceifada por intransigência das autoridades.

Já no art. $5^{\circ}$ estão estabelecidos os direitos do colaborador a partir do momento em que se homologa o acordo de delação. São eles:

Art. $5^{\circ}$. São direitos do colaborador:

I - usufruir das medidas de proteção previstas na legislação específica;

II - ter nome, qualificação, imagem e demais informações pessoais preservados;

III - ser conduzido, em juízo, separadamente dos demais coautores e partícipes; 
IV - participar das audiências sem contato visual com os outros acusados;

$\mathrm{V}$ - não ter sua identidade revelada pelos meios de comunicação, nem ser fotografado ou filmado, sem sua prévia autorização por escrito;

VI - cumprir pena em estabelecimento penal diverso dos demais corréus ou condenados.

Cumulativamente aos direitos do delator elencados no art. $5^{\circ}$. da lei $n^{\circ} 12.850 / 2013$, pode-se constatar que o art. $7^{\circ}$ da Lei $n^{\circ} .9 .807 / 99$ estabelece normas para a proteção a vítimas e a testemunhas, podendo ser aplicadas caso haja necessidade, sendo entendido ainda que também constitui um dever do colaborador zelar pela compatibilidade entre sua conduta e a proteção definida, sob pena de perdê-la, segundo se depreende dos termos do art. 10, II, “b”, da Lei 9.807/99.

É importante destacar que o diploma legal aponta em seu art. $7^{\circ}$ o necessário sigilo na distribuição da homologação do acordo, de maneira que neste deve constar apenas as informações que não acarretem na identificação do delator nem de seu objeto, condições estas que devem ser mantidas até a fase processual e relacionadas as provas já produzidas, uma vez que, por autorização judicial, os advogados dos partes representadas poderão ter acesso as declarações do colaborador para fins de contraditório e defesa, como também poderão arguir questionamentos durante seu depoimento em juízo. Essa previsão visa assegurar a incolumidade do delator assim como a segurança das investigações. No oferecimento da denúncia o sigilo deixa de existir, porém as prerrogativas apontadas no art. $5^{\circ}$ continuam a serem aplicadas.

Com o fim de garantir a proteção à identidade e segurança do colaborador, Gonçalves e Baltazar Júnior (2016, p. 659) descrevem que 
também é admitida a retificação do registro civil para alteração do seu nome, com fundamento no art. $9^{\circ}$ da Lei n. 9.807/99 e arts. 57, $\S 7^{\circ}$, e 58, parágrafo único, da Lei de Registros Públicos (LRP), notadamente esta é uma medida voltada a prevenir tentativas de vingança.

Vislumbra-se a partir destas considerações que a colaboração premiada, segundo os termos da Lei $n^{\circ} 12.850 / 2013$, muito mais transparece ser uma forma de justiça consensual do que uma forma "negocial", possibilitando, portanto, que ela atenda ao interesse da persecução penal.

\section{IMPLICAÇÕES DO EMPREGO DA DELAÇÃO}

\subsection{Críticas ao Instituto}

A principal crítica quanto a delação premiada diz respeito a infringência da ética, uma vez que o delator é "incentivado" a trair os seus em benefício próprio. Assegura Damásio E. de Jesus (1998, p. 205), que a delação "[...] não é pedagógica, porque ensina que trair traz benefícios [...]". Num âmbito social onde minimamente subsistam preceitos éticos, a traição é inconcebível, elevando o grau de culpabilidade do agente.

Alguns críticos vislumbram ainda a existência da fragilização do papel do magistrado em face do acordo que é lavrado sem sua presença, sendo-lhe reservado um papel essencialmente passivo ou, por assim dizer, complacente, em face dos termos já tratados com o colaborador. Diante desta circunstância, adverte Vinicius Vasconcellos (2015) que há uma verdadeira "usurpação" da função decisória pois o Parquet é desde o início imbuído de aferir a culpabilidade e a pena do colaborador em razão dos benefícios que lhe são negociados, dentre os quais a possibilidade de 
deixar de oferecer denúncia (art. $4^{\circ}, \S^{\circ}$, da Lei 12.850/2013).

Não obstante, até mesmo a prática do acordo de delação feito com o criminoso é alvo de crítica pelos doutrinadores contrários ao instituto. Haja vista que estes não concebem que o Estado barganhe informações com um infrator da lei, de tal forma que esta medida apenas seria um ato de declaração de ineficiência prática de sua capacidade investigativa frente ao avanço das organizações. Segundo este norte, Yarochewsky (2012, p. 141) esclarece:

O Estado, de um lado, incompetente e falido na sua função investigativa, vê no delator a última saída para a obtenção de informações que levem ao êxito da persecução criminal, e o delator, de outro, permanecendo na sua "ética" da malandragem, vê na delação mais uma forma de levar vantagem, com o escopo de "se livrar" de uma sanção penal.

Outras críticas situam-se além da questão ética, adentrando sob o campo principiológico, a mais patente seria a lesão ao princípio da proporcionalidade, decorrente da percepção de que a sanção penal imposta ao colaborador apresenta condições bem mais benéficas às recebidas pelos demais envolvidos nas práticas delitivas, muito embora todos estes tenham cometido os mesmos crimes.

De acordo com este balizamento, Barona Vilar (1996, p. 87) expõe que esta forma de "justiça negociada" impõe a quebra do aparato processual penal estabelecido e desvirtuamento da posição processual do sujeito-acusado, além de lesões a princípios jurídicos como o da oralidade, juiz natural, presunção de inocência ${ }^{11}$, a busca pela verdade real,

11 "Sobre todo, no hay que olvidar que el principio de presunción de inocência implica la práctica de las 
contraditório, individualização da pena, entre outros. Assim, considera que "[...] la cuestón de hasta qué punto la búsqueda de mecanismos procesales, como es la conformidade, no es sino un "remiendo" a la falta de solución penal substantiva" (VILAR, 1996, p. 88).

Observa-se, por conseguinte, que a prisão preventiva pode acabar tornando-se uma "incentivadora" a atitude colaborativa, acarretando a contaminação do processo e a distorção da presunção de não culpabilidade em relação ao delator e ao corréu não-colaborante (PEREIRA, 2013). Ainda, pode-se considerar que tal instituto aparentemente conflita com o gozo da presunção de inocência e não-autoincriminação por influir para que o delator acabe cedendo ao anseio estatal por informação, o que pode, sob certa feita, ocasionar prejuízos ao dever estatal de tutela da dignidade humana (AIRES; FERNANDES, 2017).

Nesse aspecto, pode-se considerar que há uma regressão do sistema processual, oportunidade na qual o instituto da prisão preventiva pode adotar uma funcionalidade distinta, vindo a tornar-se o instrumento principal de provocação da atitude colaborativa, levando o imputado quase à condição de meio de prova. Com isso, o processo acaba por sofrer uma perversa distorção ao assumir uma condição policialesca, investigativa ou até inquisitorial e, consoante observação de Pereira (2013), nestes casos o juiz pode assumir simbolicamente a postura de combatente contra a criminalidade organizada e aí vir esvaziar a significação principiológica da presunção da inocência e não-autoincriminação, o que também não deixa de claramente conflitar com a imparcialidade que lhe é requerida. (VILAR, 1996, p. 87). 


\subsection{Considerações Positivas}

Partindo do entendimento que o delito representa o rompimento do pacto social, constituindo o prelúdio da dissuasão da convivência comunitária harmónica, há de se considerar que o uso dos recursos legítimos para ilidir tal prática não pode ser entendido como falta ética ou moral, desta maneira teleologicamente deve-se perquirir instrumentos eficientes para prevenir e reprimir a reprodução dos comportamentos ilícitos.

Segundo este raciocínio, não se pode argumentar que a delação vai de encontro a ética por estimular a traição, sobretudo porque não há parâmetros éticos no meio criminoso, justamente porque a prática delituosa, por si só, representa a desídia inconteste com as normas de convivência social e falta de compromisso com os interesses e bens coletivos $^{12}$.

Sob esta perspectiva, encontra-se na relevância dos vetores funcionalidade e eficiência, apreciados diante do caso concreto, o fundamento da aplicação da colaboração premiada, ainda que aparentemente isso possa conflitar ou até mesmo dispensar postulados prescindível em prol de uma maior eficiência processual, de modo que não se prejudiquem os postulados essenciais, tais quais a incolumidade e ordem pública, a administração da justiça, a tutela da vida, entre outros.

A delação, ao ser considerada como "traição", estaria relacionada com a quebra de fidelidade prometida e empenhada, representada pelo rompimento de vínculos, os quais notadamente já estão recortados do âmbito social e jurídico, de tal maneira o único liame a ser dissuadido

12 Neste norte, leciona Guilherme Nucci $(2015$, p. 45$)$ ao dizer que “[...] no universo criminoso, não se pode falar em ética ou em valores moralmente elevados, dada a própria natureza da prática de condutas que rompem as normas vigentes, ferindo bens jurídicos protegidos pelo Estado". 
seria da união existente na organização criminosa, o que, por se só, não pode ser deixado de considerar como o reconhecimento da inadequação da conduta particular e uma contribuição para a sociedade, simbolizando o início do restabelecimento dos laços sociais. Neste interim, é de bom alvitre destacar as palavras de Fabiana Greghi (2007, p. 20):

[...] os valores morais devem ser arguidos em defesa da sociedade e não para garantir a impunidade de criminosos que inclusive são capazes de matar seus comparsas - "queima de arquivos" - para impedirem que eles entreguem a organização criminosa às autoridades.

Ao tratar desta forma consensual de se perquirir respostas penais, é interessante destacar que o Estado já pratica acordos com infratores desde a edição da lei 9.099/95, quando prevê em seu art. 76 a transação penal. Não obstante, vê-se que seu objetivo se circunscreve a garantia da estabilidade das relações sociais e a regulação das condutas individuais para harmonizar a convivência, restaurando o status quo anterior ou mesmo aplicando uma medida retributiva, adequada e proporcional à lesividade do bem jurídico afetado.

Assim, o Direito ao adotar a delação como meio para obtenção de prova busca debelar as ações criminosas que atentam contra o equilíbrio da comunidade, onde a colaboração premiada constitui um recurso que se utiliza dos próprios agentes criminosos para reprimir o crime, o que representa uma estratégia presente na literatura antiga ${ }^{13}$.

Como já dito em linhas anteriores, as organizações criminosas detêm grande influência e capacidade para desestabilização de um sistema

13 Como exemplo, pode-se citar a passagem do livro “AArte da Guerra” de Sun Tzu (2006, p. 15): "Quando o inimigo estiver unido, divide-o. Ataca-o, quando ele estiver despreparado. Irrompe onde ele menos espera. Tais são as estratégias da vitória". 
democrático, não sendo razoável o Estado abrir mão da colaboração de um envolvido conhecedor de todo funcionamento, que possui animus em denunciar coautores e partícipes, que certamente contribuirá efetivamente no combate ao crime.

Quanto aos questionamentos de ordem principiológica, os defensores do instituto entendem que não há transgressões ou a desestabilização do processo penal, uma vez que seu rito é previamente definido, há a participação voluntária do colaborador, que inclusive deve ser assistido a todo momento por um defensor, além do que os denunciados terão a oportuna possibilidade de exercer seus direitos à ampla defesa e contraditório ${ }^{14}$ no transcurso do processo, momento em que o conteúdo da delação deixa de ser elemento de informação (para fins de investigação) para tratar-se de instrumento probatório, ocasião em que o depoimento do delator passa a gerar repercussão jurídica no transcurso do processo, não apenas pelo seu conteúdo que poderá ser ratificado ou refutado, mas até mesmo pela questão procedimental, uma vez que ele poderá ser indagado pelas partes envolvidas.

Ao considerar a redução do grau de culpabilidade do colaborador, aponta Nucci (2015, p. 45) que "[...] o delator, ao colaborar com o Estado, demonstra menor culpabilidade, portanto, pode receber sanção menos grave". Ademais, em sendo a culpa um juízo de valor variável ${ }^{15} \mathrm{em}$ face da reprovabilidade da conduta do agente, é plenamente cabível a aplicação de pena menor para aqueles que se dispõe em cooperar com os órgãos judiciais, possibilitando, inclusive, sua recontextualização processual.

A partir destas condições, passa-se a tratar do exemplo italiano

14 "O fato de existir um acordo de colaboração premiada não afastará a dialeticidade do processo, de modo que a sentença seja síntese do contraditório e da ampla defesa" (GOMES; SILVA, 2015, p. 173).

15 "A culpabilidade é um juízo de reprovação pessoal, feito pelo autor de um fato típico e antijurídico, porque, podendo se comporta conforme o direito, o autor do referido fato optou livremente por se comportar contrário ao direito". (BRANDÃO, 2003, p. 132) 
de enfrentamento da máfia ao final da década de 1980, oportunidade na qual a Delação Premiada foi eficazmente empregada.

\section{O CASO ITALIANO: O PAPEL DE TOMMASO BUSCETTA}

Apontado como um dos mais importantes fatos relacionados ao emprego da delação premiada em âmbito internacional, o combate a máfia italiana no final da década de 1980 ganhou impulso a partir da colaboração de Tommaso Buscetta, o que possibilitou o desmantelamento da organização criminosa "Cosa Nostra".

Tommaso Buscetta, era um ex-integrante da organização "Cosa Nostra" e por muito tempo participou da máfia italiana. Devido a uma disputa de poder interno, sobretudo pela acentuada exploração da violência pelo grupo dos corleoneses, decidiu fugir para viver em outros países. Ele foi encontrado e preso por duas vezes no território brasileiro, em 23 de outubro de 1983 e em 3 de julho de 1984, sendo posteriormente extraditado. Nesta última oportunidade, tentou o suicídio, mesmo assim foi encaminhado para Itália, chegando no dia 15 de julho de 1984, quando aceitou contar o que sabia e realizar a delação dos nomes dos envolvidos, da estrutura da organização e de seu modus operandi (O GLOBO, 2013a).

A colaboração de Buscetta e o papel do juiz Giovanni Falcone foram decisivos para instauração do "Maxx Processo", chamado assim por investigar 474 supostos integrantes da organização criminosa. Ao final, este alcançou resultados incríveis, obtendo 338 condenações que somaram 2.665 anos de prisão, além de 19 prisões perpétuas e apenas 117 réus foram absolvidos (O GLOBO, 2013b). Entre os nomes apontados por Buscetta, se destacou o de Giulio Andreotti, diversas vezes chefe de governo, sendo indicado como o representante mais elevado da 
máfia na política (O GLOBO, 2013a). Dessa forma, apenas em razão das revelações de Tommaso toda a direção da máfia siciliana pode ser condenada ${ }^{16}$.

Não obstante, Tommaso Buscetta conseguiu que sua esposa brasileira e seu filho fossem atendidos pelo serviço de proteção e encaminhados para os Estados Unidos, lugar onde ele também veio a cumprir sua pena, já com nacionalidade, identidade e proteção do programa de testemunhas, vindo a morrer em 2000, aos 71 anos, em decorrência de problemáticas de saúde (O GLOBO, 2013a).

\section{CONCLUSÃO}

Embora ainda pecando quanto a latente impunidade de crimes mais gravosos, o legislador pátrio foi venturoso ao editar a lei 12.850/13, disciplinando os aspectos processuais da colaboração premiada, sobretudo ao estabelecer as garantias e funções das partes, bem como o procedimento para a colaboração.

Ao arremate do que fora exposto durante o trabalho, a delação premiada constitui um importante instrumento na repressão ao crime organizado. Na contramão das críticas, o uso deste instituto, desde que dentro dos padrões legais estabelecidos, favorece a persecução criminal no enfrentamento a estas organizações permitindo a quebra da lei do silêncio e superação das barreiras que dificultam o alcance dos líderes. Não obstante, a possibilidade de delação mediante benesse cria uma desagregação da solidariedade interna em face da expectativa

16 Em retaliação, o magistrado Giovanni Falcone foi assassinado em 23 de maio de 1992 quando trafegava na autoestrada que ligava o aeroporto de Punta Raisa (hoje chamado Falcone-Borsellino) a Palermo, oportunidade na qual foi explodido o duto subterrâneo de escoamento de águas pluviais que cortava a rodovia por onde ele passaria (IBGF, 2008). 
de ter a pena reduzida ${ }^{17}$, além disto não é concebível arrazoar a ética como esteio para críticas à colaboração premiada, quando esta tem como fim o enfrentamento a criminalidade organizada e demonstra, segundo experiências estrangeiras e nacionais, ter importantes resultados criminais.

Vale ainda destacar que, ao se combater a influência e reincidência delitiva das organizações criminosas, cujas ações causam prejuízos sociais terríveis, a citar: a prática de crimes violentos (homicídios, extorsões, sequestros...), tráfico de drogas, lavagem de dinheiro, entre tantos, vislumbra-se que a colaboração premiada, enquanto instituto de cunho informativo e favorável a persecução penal, corresponde a uma importante medida para garantia da harmonia social e estabilidade das condições de existência do Estado Constitucional de Direito.

\section{REFERÊNCIAS}

AIRES, Murilo T.; FERNANDES, Fernando A. A colaboração premiada como instrumento de política criminal: a tensão em relação às garantas fundamentais do réu colaborador. Revista Brasileira de Direito Processual Penal, Porto Alegre, vol. 3, n. 1, p. 253-284, jan./ abr. 2017. Disponível em: <htps://doi.org/10.22197/rbdpp.v3i1.46>. Acesso em 10 set. 2017.

ANDRADE, Wemerson Pedro de. Organização criminosa: Por uma melhor compreensão. In: Âmbito Jurídico, Rio Grande, XIII, n. 83, dez 2010. Disponível em: <http://www.ambito-juridico.com.br/site/ index.php?n_link=revista_artigos_leitura\&artigo_id=8714 $>$. Acesso

17 Conforme aponta Nucci $(2015$, p.46), “[...] a rejeição à ideia da colaboração premiada constituiria um autêntico prêmio ao crime organizado e aos delinquentes em geral, que, sem a menor ética, ofendem bens jurídicos preciosos, mas o Estado não lhes poderia semear a cizânia ou a desunião, pois não seria moralmente aceitável. Se os criminosos atuam com regras próprias, pouco ligando para a ética, parece-nos viável provocar-lhes a cisão, fomentando a delação premiada". 
em maio 2016.

BARROS, Mariana. A delação premiada veio pra ficar. VEJA. 07/08/2015. Disponível em:<http://veja.abril.com.br/noticia/brasil/adelacao-premiada-veio-para-ficar>. Acesso em 03 maio 2016.

BITTAR, Walter Barbosa; PEREIRA, Alexandre Hagiwara. Delação Premiada. Rio de Janeiro: Lúmen Júris, 2011.

BRANDÃO, Claudio. Teoria Jurídica do Crime. Rio de Janeiro: Editora Forense, 2003.

BRASIL. Decreto-lei no 2.848, de 07 de dezembro de 1940. Código Penal. Disponível em: <http://www.planalto.gov.br/ccivil_03/decretolei/Del2848compilado.htm>. Acesso em 22 fev. 2016.

. Lei $\mathrm{n}^{\mathrm{0}} 7.492$, de 16 de junho de 1986. Disponível em: <http:// www.planalto.gov.br/ccivil_03/LEIS/L7492.htm>. Acesso em 22 fev. 2016.

. Lei $\mathrm{n}^{\circ} 8.072$, de 25 de julho de 1990. Disponível em: $<$ http:// www.planalto.gov.br/ccivil_03/LEIS/L8072.htm>. Acesso em 22 fev. 2016.

. Lei ${ }^{\circ} 8.137$, de 27 de dezembro de 1990. Disponível em: $<$ http://www.planalto.gov.br/ccivil_03/leis/L8137.htm> Acesso em 30 abr. 2016.

. Lei $\mathrm{n}^{\circ}$ 9.034, de 03 de maio de 1995. Disponível em: < http:// www.planalto.gov.br/ccivil_03/leis/L9034.htm>. Acesso em 10 set. 2016.

. Lei $\mathrm{n}^{\circ}$ 9.080, de 19 de julho de 1995. Disponível em: <http:// www.planalto.gov.br/ccivil_03/leis/L9080.htm>. Acesso em 30 abr. 
2016.

Lei $n^{\circ} 9.099$, de 26 de setembro de 1995. Disponível em: $<$ http://www.planalto.gov.br/ccivil_03/leis/L9099.htm>. Acesso em 30 abr. 2016.

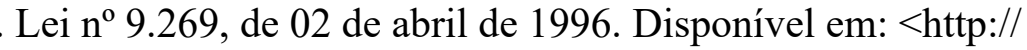
www.planalto.gov.br/ccivil_03/LEIS/L9269.htm\#art1>. Acesso em 10 set. 2016.

. Lei $\mathrm{n}^{\circ}$ 9.613, de 3 de março de 1998. Disponível em: <http:// www.planalto.gov.br/ccivil_03/leis/L9613.htm>. Acesso em 30 abr. 2016.

. Lei $\mathrm{n}^{\circ}$ 9.807, de 13 de julho de 1999. Disponível em: <http:// www.planalto.gov.br/ccivil_03/LEIS/L9807.htm>. Acesso em 22 abr. 2016.

. Lei $\mathrm{n}^{\mathrm{o}} 11.343$, de 23 de agosto de 2006. Disponível em: $<$ http://www.planalto.gov.br/ccivil_03/_ato2004-2006/2006/lei/ 111343.htm>. Acesso em 30 abr. 2016.

. Lei $\mathrm{n}^{\mathrm{o}} 12.529$, de 30 de novembro de 2011. Disponível em: $<$ http:/www.planalto.gov.br/ccivil_03/_ato2011-2014/2011/Lei/ L12529.htm>. Acesso em 30 abr. 2016.

. Lei $\mathrm{n}^{\mathrm{o}} 12.846$, de $1^{\mathrm{o}}$ de agosto de 2013. Disponível em: $<$ http://www.planalto.gov.br/ccivil 03/ ato2011-2014/2013/lei/ 112846.htm>. Acesso em 30 abr. 2016.

. Lei $\mathrm{n}^{\mathrm{o}} 12.850$, de 2 de agosto de 2013. Disponível em: $<$ http://www.planalto.gov.br/ccivil_03/_ato2011-2014/2013/lei/ 112850.htm >. Acesso em 22 fev. 2016. 
. Supremo Tribunal Federal. Ação Penal 470 MG. Réus: José Dirceu de Oliveira e Silva e outros. Relator Min. Joaquim Barbosa. 18/04/2012. DJe-079, divulgado 23/04/2012, publicado 24/04/2012.

CARDOSO, Fabio Fettuccia. A delação premiada na legislação brasileira. JusBrasil, 2015. Disponível em: <http://fabiofettuccia. jusbrasil.com.br/artigos/174959721/a-delacao-premiada-na-legislacaobrasileira>. Acesso em 20 abr. 2016.

CORREIA, Emanuelle Araújo; OLIVEIRA, Kennya Kelli Rangel. Inovações da lei $\mathrm{n}^{\mathrm{o}} 12.850$, de 02 de agosto de 2013, no tocante a colaboração premiada. FACTUM - Periódico Jurídico da Católica do Tocantins, n. 2., abr. 2016, pp. 141-164.

DIAS, Pamella Rodrigues; SILVA, Erik Rodrigues da. Origem da delação premiada e suas influências no ordenamento jurídico brasileiro. JusBrasil. Disponível em: $<$ http://rafaelparanagua. jusbrasil.com.br/artigos/112140126/origemdadelacaopremiada esuasinfluenciasnoordenamentojuridicobrasileiro $>$. Acesso em 28 abr. 2016.

\section{ÉPOCA NEGÓCIOS. As 5 maiores organizações criminosas do} mundo. 2014. Disponível em: $<$ http://epocanegocios.globo.com/ Informacao/Dilemas/noticia/2014/09/5-maiores-organizacoescriminosas-do-mundo.html>. Acesso em 03 maio 2016.

FONSECA, C. B. G. et. al. A Colaboração Premiada Compensa? Brasília: Núcleo de Estudos e Pesquisas/ CONLEG/Senado, agosto/2015 (Texto para Discussão no 181). Disponível em: <www. senado.leg.br/estudos>. Acesso em 31 ago. 2015.

GOMES, Luiz Flávio; SILVA, Marcelo Rodrigues da. Criminalidade Organizada e Justiça Penal Negociada: Delação Premiada. In.:

FIDES, Natal, v.6, n. 1, jan./jun. 2015, pp. 164-175. 
GONÇALVES, Victor Eduardo Rios; BALTAZAR JÚNIOR, José Paulo. Legislação penal especial. 2. ed. São Paulo: Saraiva, 2016.

GRECO FILHO, Vicente. Comentários à Lei de Organização Criminosa: Lei n. 12.850/13. São Paulo: Saraiva, 2014.

GREGHI, Fabiana. A delação Premiada no combate ao crime organizado. Revista de Direito Público, Londrina, v. 2, n. 3, set./dez. 2007, p. 3-24.

HERKENHOFF, João Baptista. Delação premiada. Jusbrasil. 25/03/2015. Disponível em: $<$ http://joaoherkenhoff.jusbrasil.com.br/ artigos/173950010/delacao-premiada $>$. Acesso em 20 abr. 2016.

INSTITUTO BRASILEIRO DE CIÊNCIAS CRIMINAIS GIOVANNI FALCONE (IBGF). A Cosa Nostra, há 16 anos, dinamitava o juiz Giovanni Falcone, sua mulher e homens da escolta. 2008. Disponível em: $<$ http://www.ibgf.org.br/index.php?data[id_secao] $=2 \&$ data[id_ materia] $=1642>$. Acesso em 10 abr. 2016.

JESUS, Damásio Evangelista de. Direito Penal. São Paulo: Saraiva, 1998.

LAMEIRÃO, Cláudio Marcos Romero. Direito Internacional Penal: uma análise acerca do instituto da infiltração policial como método de combate aos delitos transnacionais. In.: ORBIS: Revista Científica, v. 4., n. 1., mar./2014. pp. 42-54.

\section{. A infiltração policial como instrumento de combate aos}

delitos perpetrados por organizações criminosas. Dissertação (Mestrado em Direito Internacional). Santos: Universidade Católica de Santos, 2015. 
LANA, Cristiano Teixeira Rodrigues. O instituto da delação premiada e sua efetividade no combate às organizações criminosas. Conteúdo Jurídico, Brasília-DF: 03 mar. 2015. Disponível em: $<$ http://www. conteudojuridico.com.br/artigo,o-instituto-da-delacao-premiada-esua-efetividade-no-combate-as-organizacoes-criminosas,52633.html>. Acesso em 25 abr. 2016.

\section{LIMA, Renato Brasileiro de. Legislação Criminal Especial}

Comentada. 3. ed. rev. Atual. Salvador: Editor Jus Podivm, 2015.

MENDES, Soraia da Rosa. Editorial dossiê "Colaboração premiada e justiça criminal negociada": novos e múltiplos olhares. Revista Brasileira de Direito Processual Penal, Porto Alegre, vol. 3, n. 1, p. 31-38, jan./abr. 2017. Disponível em: <htps://doi.org/10.22197/rbdpp. v3i1.56>. Acesso em 10 set. 2017.

MENDONÇA, Andrey Borges de. A Colaboração premiada e a nova Lei do Crime Organizado (Lei 12.850/2013). Custos Legis, ISSN 2177-0921, vol. 4, 2013.

\section{MINISTÉRIO PÚBLICO FEDERAL. A Lava Jato em números no}

Paraná. Disponível em: < http://www.mpf.mp.br/para-o-cidadao/casolava-jato/atuacao-na-1a-instancia/parana/resultado $>$. Acesso em 25 out. 2017.

NUCCI, Guilherme de Souza. Organização criminosa. 2 ed., rev. amp. Rio de Janeiro: Forense, 2015.

O GLOBO. 1987: máfia sofre julgamento histórico. Tribunal especial foi montado em Palermo e 357 bandidos foram condenados. 2013. Disponível em: <http://acervo.oglobo.globo.com/fatoshistoricos/1987-mafia-sofre-julgamento-historico-9954179>. Acesso em 23 abr. 2016. 
. Preso em São Paulo, Tommaso Buscetta delatou mais de 300 mafiosos italianos. 2013. Disponível em: <http://acervo.oglobo.globo. com/em-destaque/preso-em-sao-paulo-tommaso-buscetta-delatoumais-de-300-mafiosos-italianos-10493312\#>. Acesso em 23 abr. 2016.

PEREIRA, Frederico Valdez. Delação premiada. Curitiba: Juruá, 2013.

QUEZADO, Paulo; VIERGINIO, Jamile. Delação premiada. Fortaleza: Gráfica Fortaleza, 2009.

SANTOS, Marcos Paulo Dutra. Colaboração (delação) premiada. Salvador: Juspodivm, 2016.

SILVA, Marcelo Rodrigues da. A colaboração premiada como terceira via do direito penal no enfrentamento à corrupção administrativa organizada. Revista Brasileira de Direito Processual Penal, Porto Alegre, vol. 3, n. 1, p. 285-314, jan./abr. 2017. Disponível em: <htps:// doi.org/10.22197/rbdpp.v3i1.50>. Acesso em 10 set. 2017.

TZU, Sun. A arte da guerra. Tradução de Sueli Barros Cassal. Porto Alegre: L\&PM, 2006.

VALADARES, João. Juristas e STF discordam com relação à delação premiada. Correio Brasiliense. 14/09/2015. Disponível em: <http:// www.correiobraziliense.com.br/app/noticia/politica/2015/09/14/ internas_polbraeco,498469/juristas-e-stf-discordam-com-relacao-adelacao-premiada.shtml>. Acesso em: 22 mar. 2016.

\section{VASCONCELLOS, Vinícius Gomes de. Barganha e Justiça Criminal Negocial. São Paulo: IBCCRIM, 2015.}

VILAR, Sílvia Barona. La conformidad em el proceso penal y la justicia negociada. In: CONRADI, Faustino Gutiérrez-Alviz (Dir.). La 
Criminalidad Organizada ante la Justicia. Sevilla: Universidad de Sevilla, 1966. p. 85-106.

WAGNER; Felipe Alexandre; ZART, Ricardo Emílio. O instituto da colaboração premiada à luz da Lei das Organizações Criminosas (Lei $\mathrm{n}^{\circ}$ 12.850/13): uma análise material, processual e constitucional. Ponto de Vista Jurídico, Caçador, v.5, n. 2, p. 20-34, jul./dez. 2016.

YAROCHEWSKY, Leonardo Isaac. Delação Premiada no Projeto de Reforma do Código Penal: Nova Roupagem, Antigos Problemas. R. EMERJ, Rio de Janeiro, v. 15, n. 60, p. 126-142, out.-dez. 2012.

Como citar: SILVA, Allan Jones Andreza; SILVA, Luciano Nascimento; SILVA, Andrey Jonas Andreza. O instituto da delação premiada no combate as organizações criminosas. Revista do Direito Público, Londrina, v. 13, n. 1, p. 110-149, abr. 2018. DOI: 10.5433/1980-511X2018v13n1p110. ISSN: 1980-511X.

Recebido em: 19/09/2016

Aprovado em: 06/04/2018 